\title{
A proposal for classification of tooth fractures based on treatment need
}

\author{
Kapil Loomba ${ }^{1)}$, Anju Loomba ${ }^{2)}$, Rhythm Bains ${ }^{1)}$ and Vivek K. Bains ${ }^{3)}$ \\ ${ }^{1)}$ Department of Conservative Dentistry and Endodontics, Saraswati Dental College and Hospital, \\ Lucknow, India \\ ${ }^{2)}$ Department of Orthodontics and Dentofacial Orthopedics, Saraswati Dental College and Hospital, \\ Lucknow, India \\ ${ }^{3)}$ Department of Periodontics, Saraswati Dental College and Hospital, Lucknow, India
}

(Received 25 May and accepted 28 September 2010)

\begin{abstract}
Accuracy in defining a disease makes it easier to study and understand. Similarly, with injuries to the teeth, a comprehensive classification is an aid to correct diagnosis and treatment planning. A thorough review of various classifications of tooth fractures shows that, despite an emphasis on traumatic dental injuries, a consensus needs to be arrived at, especially among clinicians and general/family dentists. The ideal classification would be applicable to both primary and permanent dentition, based on tooth fractures in both the horizontal and vertical planes, encompassing all possible sites, easy to comprehend, communicable amongst health professionals and clinically relevant. With recent improvements in conservative techniques, it is now clinically possible to preserve natural teeth even if they have been horizontally or vertically fractured, and thus an in-depth understanding and knowledge of tooth fractures, together with a simplified classification, is now more than ever essential. (J Oral Sci 52, 517 529,2010 )
\end{abstract}

Keywords: classification; horizontal tooth fracture; vertical tooth fracture.

\section{Introduction}

Conservation is fast becoming the basis of human activity

Correspondence to Dr. Kapil Loomba, 3 Park Lane, Lucknow, UP 226001, India

Tel: +91-9198207777

Fax: +91-5222621237

E-mail: kapilloomba61@yahoo.in in many fields. In dentistry, teeth that were once considered irreparable after fracture and recommended for extraction can now be preserved, especially since the advent of dental adhesives. Traumatic dental injury is a neglected oral condition, despite its relatively high prevalence and significant impact on individuals and society (1).

Depending on the sex and age of children worldwide, the proportion of tooth injury varies from $4 \%$ to $33 \%$ (24) with a peak age between 18 months and 3.5 years of age (5). Reports suggest that most dental injuries occur during first two decades of life, usually around 8 - 12 years (6), and that $70 \%$ of such injuries involve the maxillary central incisors followed by maxillary lateral incisors and mandibular incisors (6-9). Depending on age, the incidence is higher in boys than in girls, with male:female ratios varying from $2: 1$ to $3: 1(2,10)$. The role of socioeconomic status on traumatic dental injuries seems to be unclear, but a few reports have suggested a higher incidence among adolescents from families with higher socioeconomic status (11). The most common type of dental trauma is coronal fracture of the enamel and dentin, without pulp involvement $(6,12)$. Among permanent dentition, crown fractures comprise $26-76 \%$ of all permanent tooth injuries (13) and $0.5 \%$ to $7 \%$ of injuries involve root fracture $(14,15)$. A study of 84 treated permanent incisors with root fracture found that $17 \%$ of the fractures occurred in the apical third, $56 \%$ in the middle third, $27 \%$ in the gingival third, and $29 \%$ in the crown, involving enamel and dentine (15).

Vertical root fractures account for 2-5\% of crown/root fractures (15-18), and in at least 3.69\% of endontically treated teeth, a greater proportion occurring in patients older 
than 40 years (19). However, some reports have suggested that the prevalence of vertical root fractures may be as high as $10.9 \%$ (20) and $12.9 \%$ (21). The period between vertical root fracture and root canal treatment reportedly varies from 3 days to 14 years, while some reports have suggested average periods of 39 and 52.5 months $(17,22,23)$. Although there has been variation among the sites of vertical fracture reported in various studies, there is a general trend for vertical fracture to be more common in posterior teeth (24), with the highest prevalence in premolars (27.2\% to $60.4 \%)$ followed by molars (13\% to $25 \%$ ) and incisors (5.6\% to $22.6 \%)(25-27)$, although some reports have considered that the second mandibular molar is most commonly involved $(28,29)$. A few reports have suggested that vertical fracture occurs in a buccolingual direction in the anterior teeth and individual molar roots $(23,30)$, although Silvestri (31) also described fractures on the mesial and distal surfaces of roots extending in a mesiodistal direction.

Traumatic dental injury can result in damage to both dental and periradicular structures. It may cause injury to the pulp, with or without damage to the crown and/or root, or in severe cases, tooth displacement. Traumatic dental injuries (TDI) have been classified on the basis of many factors such as etiology, anatomy, pathology, therapeutic considerations and degree of severity (1). The latest classification suggested by Glendor, Marcenes and Andreasen (1) is a modification of the WHO version (32). Documented cases suggest that horizontal fractures can be managed comparatively more easily and successfully than vertical root fractures, the latter representing one of the most frustrating diagnostic and management challenges in endodontics and restorative therapy $(28,29,33-38)$.

Accuracy in defining a condition or disease makes it easier to study and understand. Similarly, a comprehensive classification of tooth injuries is an aid to correct diagnosis and treatment planning. However, a review of the literature reveals much variation in the standardization and methodology of TDI classification (1). According to Johnson (39), "The most widely used method is the Ellis classification (40), which is based on a numerical system that describes the anatomical extent of the injury". Additionally, he was of opinion that "Andreasen's classification (41) is based on anatomical and therapeutic considerations and may be utilized with permanent and primary dentition. These two commonly used methods are not readily understood by lay people and members of other health professions". He further added that "because of the increased incidence of medical and dental litigation, a necessary aspect of any classification system is provision of an accurate description of injury that can be easily understood by individuals with differing educational backgrounds" (39). It is generally agreed that patients with dental injury comprise an important referral group, together with family/general dentists who refer such patients to specialists, and for whom communication plays a vital role. Also, Spinas and Altana (42) have stated "The traditional classifications (Andreasen, Ellis) did not satisfy us for different reasons. In fact, they only consider the initial lesion situation, never focusing on the shape of the lesion for providing validity to materials used for restorations." According to them, a classification should simplify communication among practitioners, thus confirming its importance in deciding optimal diagnostic and therapeutic protocols (42). Furthermore, incorporation of open-ended groupings such as "other injuries including laceration of oral soft tissues" in the WHO classification may lead to misinterpretation by investigators (32).

Thus there is a need for a classification that reflects anatomically the direction and fracture location of the tooth, whether it involves the alveolar bone and neighbouring soft tissues, and reflects the possible sign and symptoms, being more relevant to cases that are managed by conservative dentists and endodontists. It should serve its purpose judiciously and offer a simplified interpretation that can be communicated easily and promptly amongst referral groups, other health professionals and lay people. As medical disciplines become increasingly specialized, this requirement is especially relevant for conservative dentists, who must diagnose and treat fractures affecting the tooth alone, rather than fractures of structures around the tooth. Thus tooth fracture, although one type of traumatic dental injury, also has its own, individual identity.

This clinically oriented review covers the literature relating to classification of tooth fracture, and additionally describes a comprehensible classification, encompassing and focusing on all the varied aspects of tooth fractures, including those that have favorable and unfavorable prognosis.

\section{Classification}

Many classifications have been suggested for traumatic dental injuries (Table 1) (5,10,39-63). Some of those proposed initially were limited to three lines, whereas later ones were excessively complex. Close analysis reveals that these classifications placed more emphasis on traumatic dental injuries in general, giving little consideration to vertical tooth fractures. As suggested earlier, there is a need for reappraisal of tooth fractures. Any such classification should be applicable to both primary and permanent dentition, and based on tooth fractures in both the horizontal and vertical planes (Figs. 1 to 5). Such a classification should be more tooth-specific and site-specific, and should 
Table 1 Classifications of dental traumatic injuries

\begin{tabular}{|c|c|}
\hline Year & Author \\
\hline 1936 & Brauer (43) classified fractures of anterior teeth. \\
\hline 1944 & Adams (44) divided traumatized young teeth into 6 classes. \\
\hline 1946 & Hogeborn (45) classified fracture of incisors according to the degree of the break. \\
\hline 1955 & Sweet (46) classified anterior teeth. \\
\hline 1956 & Rabinowitch (47) classified injuries of the primary teeth. \\
\hline 1961 & $\begin{array}{l}\text { Ellis (40) classified anterior teeth fracture into } 6 \text { groups. (1) Enamel fracture; (2) Dentine fracture; } \\
\text { (3) Crown fracture with pulp exposure; (4) Root fracture; (5) Tooth luxation; (6) Tooth intrusion. }\end{array}$ \\
\hline 1963 & Bennett (48) classified anterior teeth. \\
\hline 1968 & Garcia-Godoy (5) gave classification for traumatic injuries to primary and permanent teeth. \\
\hline 1970 & Ellis and Davey (10) modified Ellis (39) classification and classified anterior teeth fracture. \\
\hline 1970 & Hargreaves and Craig (49) modify Ellis and Davey (23) classification. \\
\hline 1978 & Silvestri and Singh (50) classified posterior teeth fractures. \\
\hline 1978 & $\begin{array}{l}\text { WHO (51) classified oral structures injuries using code numbers while considering both primary and } \\
\text { permanent teeth. }\end{array}$ \\
\hline 1981 & $\begin{array}{l}\text { Andreasen ( } 41) \text { modified WHO (51) classification by including terms Uncomplicated/ Complicated } \\
\text { crown-root fracture and Concussion/ Subluxation/ Lateral Luxation. }\end{array}$ \\
\hline 1981 & Johnson (39) classified traumatic injuries to anterior teeth. \\
\hline 1982 & $\begin{array}{l}\text { Heithersay and Morile (52) gave classification of subgingival fracture in relation to various } \\
\text { horizontal planes of periodontium. }\end{array}$ \\
\hline 1982 & $\begin{array}{l}\text { Pulver (53) combined the classifications of Ellis and Davey (10), Andreasen (40), Hargreaves and } \\
\text { Craig (49) and Mcdonald and Avery (54) and classified traumatised teeth. }\end{array}$ \\
\hline 1983 & McDonald, Avery and Lynch (55) modified Ellis and Davey (10) classification. \\
\hline 1984 & $\begin{array}{l}\text { Leubke (56) based on separation of fragments classified root fractures into two types. Complete } \\
\text { fracture and Incomplete fracture or it can be Supraosseous fractures and Intraosseous fractures (57). }\end{array}$ \\
\hline 1985 & Ulfohn (58) classified crown fractures into three simple classes. \\
\hline 1986 & $\begin{array}{l}\text { Dean et al. (59) classified teeth fracture based on the orientation of the fracture plane to the long axis } \\
\text { of the tooth. }\end{array}$ \\
\hline 1992 & $\begin{array}{l}\text { Application of International Classification of Diseases to Dentistry and Stomatology (WHO) (60) } \\
\text { classified traumatic dental injuries and appointed codes. }\end{array}$ \\
\hline 1995 & Feiglin (61) classified transverse root fracture into three zones. \\
\hline 2001 & Dentofacial injuries classification adopted by International Association of Dental Traumatology (62) \\
\hline 2002 & Spinas and Altana (42) classified crown fractures of teeth. \\
\hline 2007 & $\begin{array}{l}\text { Berman, Blanco and Cohen (63) classified tooth injuries into Crown fractures, Root fractures and } \\
\text { Luxation injuries }\end{array}$ \\
\hline
\end{tabular}

Broad Classification of Tooth Fracture

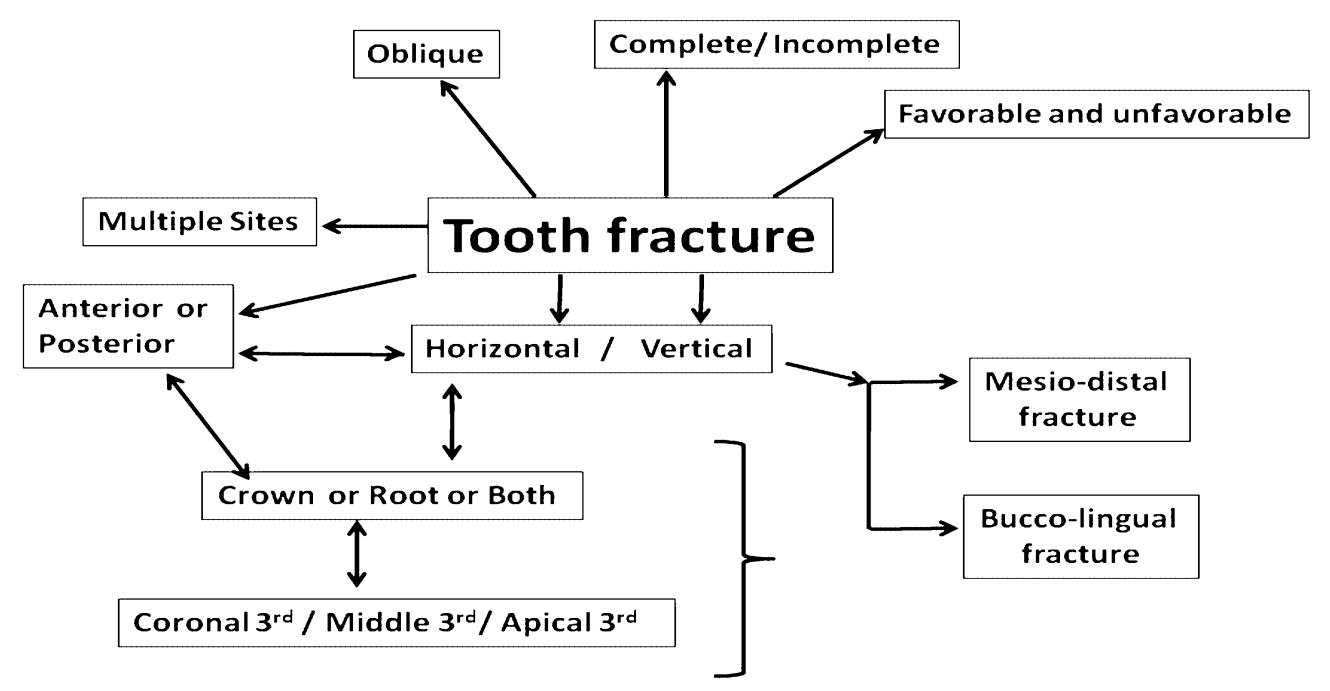

Fig. 1 Broad classification of tooth fracture. 


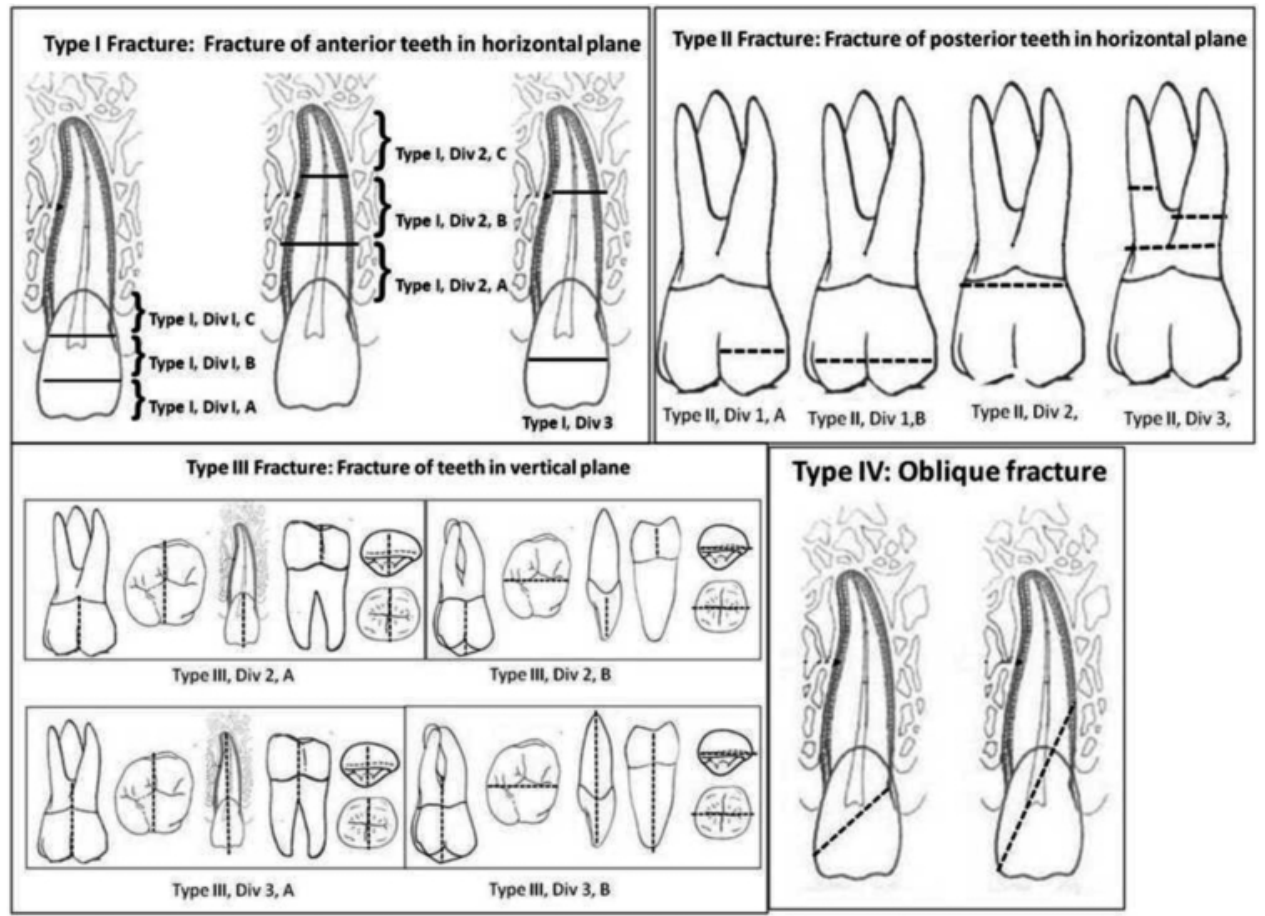

Fig. 2 Diagrammatic representation of the proposed classification.

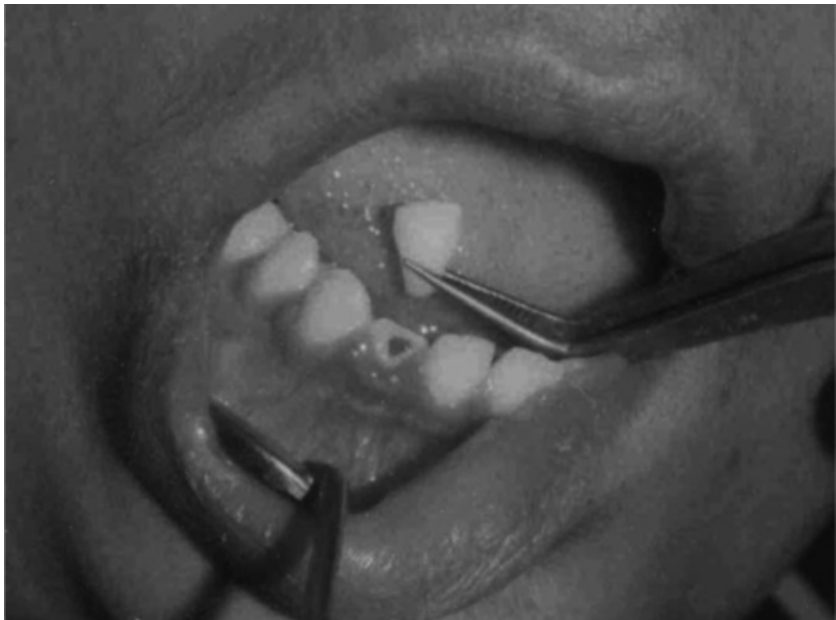

Fig. 3 Type I, Division 1, C fracture.

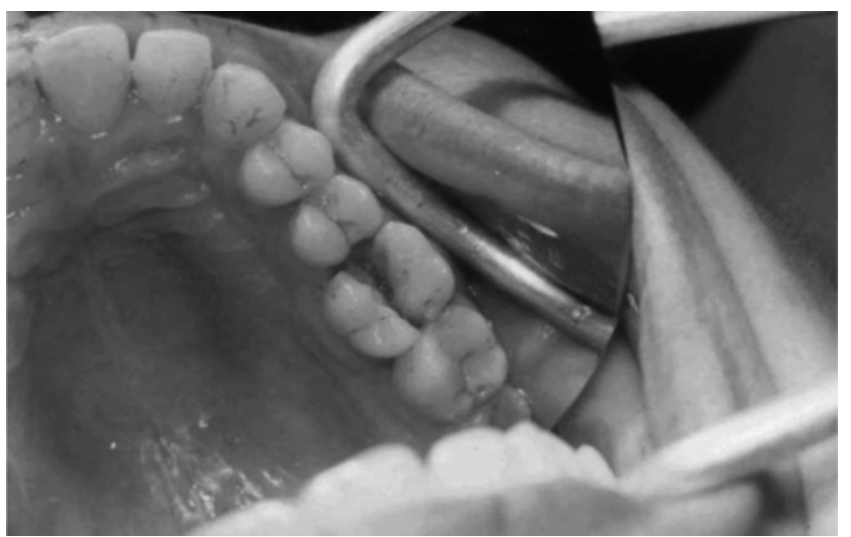

Fig. 5 Type III, Division 2, A fracture.

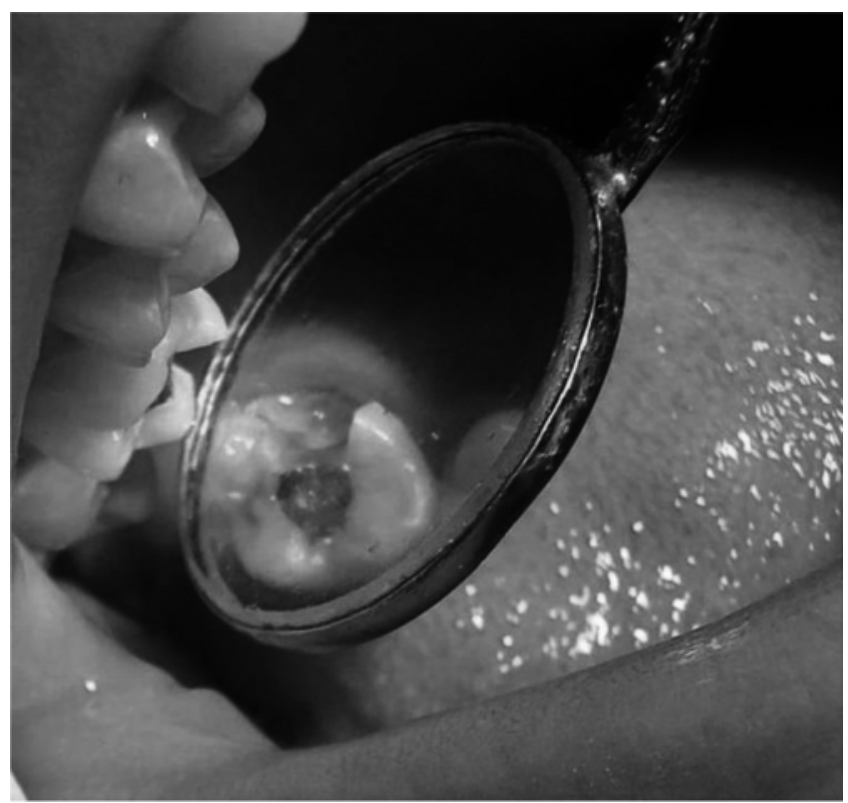

Fig. 4 Type II, Divison 1, (1 cusp fracture).

not include the dentoalveolar complex, as it is a clinical fact that patients who are referred to conservative dentists for specialized treatment are "treatment- and needoriented". Specialists more often encounter fractures in the tooth structure itself. Dentoalveolar fractures, on the other hand, are managed by oral and maxillofacial surgeons, who consider that fractures involving only teeth should be 
handled by other specialists. Hence, on the basis of clinical experience and a review of the literature, we propose the following classification:

\section{Type I: Fractures of anterior teeth in the horizontal or transverse plane.}

Division 1: Fractures of the tooth crown.

A: Fracture in the incisal one-third up to the junction of the incisal and middle third of the crown, either partial or complete.

B: Fracture in the middle one-third up to the junction of the middle and cervical third of the crown, either partial or complete.

$\mathrm{C}$ : Fracture in the cervical one-third up to the cervical line of the crown, either partial or complete.

Division 2: Fractures of the tooth root.

A: Fracture in the cervical one-third up to the junction of the cervical and middle third of the root.

B: Fracture in the middle one-third up to the junction of the middle and apical third of the root.

C: Fracture in the apical one-third of the root.

Division 3: Fractures involving both the crown and root or at multiple sites.

Type II: Fractures of the posterior teeth in the horizontal or transverse plane.

Division 1: Fractures involving the cusp/cusps.

A: Fracture involving one cusp.

B: Fracture involving two cusps.

C: Fracture involving three cusps.

D: Fracture involving four or more cusps.

Division 2: Fracture of crown en masse.

Division 3: Fracture involving root or roots.

Type III: Fractures of teeth in the vertical or longitudinal plane.

Division 1: Incomplete tooth fractures or cracked tooth syndrome.

Division 2: Vertical fractures involving tooth crowns.

A: Fracture in an anterior or posterior tooth where the fracture line passes buccolingually in the crown.

$\mathrm{B}$ : Fracture in an anterior or posterior tooth where the fracture line passes mesio-distally through the crown.

Division 3: Vertical fractures involving tooth roots.

A: Fracture in an anterior or posterior tooth where the fracture line passes buccolingually in both the crown and root, or in the root only.

B: Fracture in an anterior or posterior tooth where the fracture line passes mesio-distally through both the crown and root, or the root only.
Type IV: Oblique fractures involving the crown, root or both in anterior or posterior teeth.

Involvement of the pulp in any of these types is valid, and warrants pulpectomy treatment. Similarly, the usage of other terms such as complete/incomplete, favorable/ unfavorable etc. is also permitted in the detailed description of any of these types, according to the extent of involvement.

\section{Discussion and treatment options}

After a careful examination and anamnesis, it is the responsibility of the dentist to ensure proper care of the soft and hard tissues involved and to stabilize the fragments as far as possible, as well as establishing a proper diagnosis and classifying the type of fracture. As traumatic injury to a tooth can result in pathological changes in the periodontium, pulp and alveolar bone (44), a pulp vitality test, percussion and radiography are mandatory as a baseline for future reference. Radiography (intraoral periapical and orthopantomogram), CT scan, and even spiral CT, are diagnostically useful to ensure that no aspect of the injury is overlooked.

The presence or absence of pain, or pulpal or periodontal involvement, should be ascertained (5). For teeth with more than half of the coronal structure intact, coronal restoration (64) or reattachment may be feasible. Chosak and Eidelman (65) have developed the concept of reattachment for fractured incisors using the patient's natural crown, and this should be the first choice for restoration of fractured teeth if a usable fragment is available (66-68). Various techniques for reattachment include the use of an enamel/circumferential bevel beforehand $(69,70)$, placement of a chamfer at the fracture line after bonding $(71,72)$, use of a V-shaped enamel notch $(7,73)$, placement of an internal groove $(74,75)$ or a superficial overcontour over the fracture line (75), or simple attachment with no additional preparation (76). The use of a variety of materials as bonding agents is advocated (77-80). Hydrophilic adhesive agents with light cured/dual cured resin cement (12), bonding agents with flowable resins, hybrid or microfilled resin composites $(7,69,81-83)$, dentine adhesives with or without unfilled resins (84), dual or self-cured luting cements (75), light-cured luting cement (85), and self-etch adhesives with microhybrid composites (66) have been used with varying results (76). Developments in adhesive dentistry have improved the outcome by facilitating ultraconservative preparation techniques, and allowing "biologic restoration" (12), thus improving the esthetic outcome by retaining natural translucency and surface texture and reducing cost and chair time while increasing patient acceptance $(12,66,76,86,87)$. The recurrence of de-bonding at the interface between the tooth fragment and the 
remaining tooth structure could be considered as a "protection factor" for anterior teeth that are subjected to further trauma. Hence, any impact will not be able to reach the underlying tissues (12).

\section{Anterior tooth fracture in the horizontal plane}

Type I, Div 1, A: These comprise cases where the fracture line is in the transverse plane in the incisal one-third of the crown, resulting in conditions ranging from enamel chip-off to complete removal of the incisal edge. Here fractures are restricted to the enamel, or result in little exposure of the dentine. These are fractures with a favorable prognosis. Treatment of such cases generally consists of only smoothing any rough, jagged tooth structures if only the enamel is involved; in cases where the dentine is exposed, the exposed part should be covered with calcium hydroxide to enhance reparative dentine formation $(55,88)$. Calcium hydroxide and the sandwich technique utilizing glass ionomer cement are seen as a better alternative for cases where sensitivity to hot/cold has developed. Shortterm temporary restorative resin restorations should cover the fractured surfaces, and then after an adequate recovery period (at least 4 weeks), an esthetic resin restoration may be completed, often without removing all of the temporary resin material (88).

In cases where complete fracture of an incisal edge has occurred, reattachment of the broken fragment, if available, or composite build-up can be done. Sometimes, although there may be little or no loss of tooth structure, the vitality of a tooth may be jeopardized due to trauma. In such cases, as there are no initial signs and symptoms, pulp vitality should be checked after few weeks of follow-up and treatment should be planned accordingly.

Type I, Div 1, B: In cases where a fracture involves the middle $1 / 3$ rd of the crown, there may be pinpoint to complete pulp exposure, and this represents a diagnostic and treatment challenge, especially in cases involving immature permanent teeth. The objective of treatment in such cases is to maintain the vitality of the pulp as far as possible, and direct pulp capping or pulpotomy is the treatment of choice, although sometimes apexogenesis or apexification may be an option. Cases of vital pulp exposure should be treated as soon as possible, as unprotected pulp may be subjected to thermal insult and infection. However, in cases where there is no pulp exposure, reattachment of the fragment may be carried out with use of the latest available self-etching adhesives, although the long-term prognosis is questionable in stress-bearing areas.

Type I, Div 1, C: These are fractures of anterior teeth involving the cervical third up to the cervical line of the tooth. Treatment should involve post-core restoration after the completion of endodontic therapy, as reported in the literature $(64,89)$, but if a post and core is not feasible, such fractures are classified as having an unfavorable prognosis. For obtaining predictable restorations, McLean (90) suggested that a sound suprabony tooth structure $4.5 \mathrm{~mm}$ in height and $1 \mathrm{~mm}$ in thickness should be made available to accommodate both the periodontal biologic width $(2.5$ $\mathrm{mm}$ ) and restorative ferrule $(2 \mathrm{~mm})$. Hence, surgical crown lengthening including the removal of soft tissue alone, or both soft tissue and alevolar bone, is required. Reduction of soft tissue alone is indicated if there is an adequate attached gingiva along with more than $3 \mathrm{~mm}$ of soft tissue coronal to the bone crest. Patients with an inadequate attached gingiva and less than $3 \mathrm{~mm}$ of soft tissue require a flap procedure and bone recontouring (91).

Type I, Div 2, fractures: Andreasen et al. (92) and Caliskan and Pehlivan (93) reported that middle third root fracture was the most common type of root fracture, followed by fractures to the apical and coronal third. Clinically, a tooth with this kind of fracture appears slightly extruded with a lingually displaced crown $(61,94)$ and laterally luxated coronal segment (61). Fractures in the apical third of the root can be viewed in occlusal radiographs, whereas periapical radiographic views are better for visualizing coronally located root fractures (95). Some workers have considered that as long as a fractured tooth is undisturbed, the apical segment remains vital in $99 \%$ of cases $(61,96)$, whereas verified pulp necrosis is present in $43.7 \%$ of horizontal root fractures (97). Treatment of transverse or horizontal root fractures depends on the position of the tooth after it has been fractured, the mobility of the coronal segment, the status of the pulp, and the position of the fracture line (61). Female sex (98), young age and immature roots (98-101), diastasis between fractured fragments $(100,101)$, optimal repositioning of dislocated fragments $(<0.1 \mathrm{~mm})(100-102)$, and a positive sensitivity test result before treatment $(97,100-102)$ are other significant factors related to the type of healing rather than the type of splinting employed $(100,101)$ or usage of antibiotics (102).

Healing of coronal and apical segments can result in (a) union by hard tissue, which is the most desirable outcome, (b) fibrous tissue, (c) bony ingrowth across the fracture line, or (d) ingrowth of chronic granulation tissue, resulting in non-union (96). Although there is a greater chance of hard tissue union when a tooth is immobilized immediately after injury (61), union resulting from fibrous tissue is more common after transverse root fracture if slight mobility is present during healing $(61,96)$. Earlier splinting for a period of 8 to 10 weeks $(101,103)$ or 12 weeks $(30)$ has 
been recommended, but latest research indicates that splinting of the adjacent tooth for 2 to 4 weeks is sufficient in cases of horizontal root fracture (102), likely because of the reduced risk of replacement resorption by fixed splints that are currently in use $(104,105)$.

It has been shown that coronal third and middle third root fractures have a less favorable prognosis than apical third root fractures, perhaps due to difficulty in immobilization and exposure of the pulp to bacterial contamination in the oral environment $(101,106)$; Cvek et al. (101) and Terata et al. (94) have concluded that the chance of healing of calcified tissue is poorest when the root fracture is very close to the gingiva.

Type I, Div 2, A: These are fractures of anterior teeth where the fracture line passes through the cervical onethird of the root. Feiglin (61) has advocated that if the coronal segment is fractured above the level of the alveolar bone, then a lost tooth can be restored with a prosthetic crown after some gingival recontouring and endodontic therapy. However, if the coronal segments are splinted properly, healing may also occur (106); Andreasen et al. (102) have recommended a longer splinting period of 23 months to permit significant callus formation for root fractures located in the cervical region. If fragment immobilization is not feasible, extraction of the coronal segment is indicated. If the length of the apical segment is sufficient to maintain the crown:root ratio, forced eruption of the segment may be carried out for restoration.

Type I, Div 2, B: In cases where the fracture line passes through the middle one-third of the root, repair is hindered due to constant movement and exposure of the pulp to the oral environment. As a result, the tooth may become loose, or may be completely exfoliated due to resorption (106). Pulp necrosis occurs in the coronal segment, while the pulp remains vital in the apical part $(61,107,108)$. Hence the wide fractured foramen can be plugged using long-term treatment with calcium hydroxide $(108,109)$ or one-visit apexification with MTA $(109,110)$ and endodontic therapy for the coronal fragment only, unless periapical pathosis is seen in the apical fragment $(61,107,108)$. Occasionally, when the apical segment is long enough, intentional orthodontic eruption of the apical root can be done to expose the root surface above the alveolar crest to enable the dentist to restore the tooth with a post-core crown (106).

Type I, Div 2, C: These fractures include cases where the fracture line passes through the apical one-third of the root, with a favorable prognosis. No treatment is needed for such fractures, and only observation is required. If otherwise indicated, the tooth should be immobilized and the opposing teeth may be reduced just sufficiently to relieve any increased occlusal stresses (61,105); Qin et al. (105) have recommended an average treatment period of 4-6 weeks for apical-third root fracture using a removable splint. As discussed earlier, endodontic therapy is indicated in the coronal segment.

Type I, Div 3: In such cases there is fracture of both the crown and root, or there may be multiple fractures of both, at any level in the anterior teeth. Prognosis is dependent on the location of the fracture line; if it is located in the incisal third or middle third of the crown and the apical third of the root, prognosis may be favorable, whereas if it involves the cervical or middle third of the root along with the crown, then the prognosis may be unfavorable. Gomes et al. (111) have reported a case of fracture of both the maxillary central incisors involving fracture of the incisal third of the crown and middle third of the right, and apical third root fractures of the left central incisor, where the outcome was favorable after repositioning of the fracture fragments by splinting for 3 months, followed by root canal therapy for the coronal fragment 18 months after apexification, and restoration of the crown with acid-etching composite resin 1 week thereafter.

\section{Posterior tooth fracture in the horizontal plane}

Talim and Cohil (112) and Silvestri and Singh (50) have discussed the treatment of the most common types of fracture in the posterior teeth. Gibbs (113) and Snyder (114) suggested that treatment of fractured cusps of posterior teeth not involving the pulp can be accomplished by binding the cusps immovably together with a complete cast crown. Cusp fracture or obliquely directed complete fractures, as discussed by Silvestri and Singh (50), occur most frequently on cusps that have been weakened by a previous extensive amalgam restoration. Depending on their extent, such fractures can be treated using inlay with cusp capping, cast-gold onlay, or three-quarter crown or full crown that replaces the lost structure and protects the remaining cusps from future fracture $(50,115,116)$; one or more pin-retained amalgam restorations can be serviceable until a cast restoration is completed (50). Depending on apical extension of the fracture below the attachment apparatus or alveolar crest, gingivectomy or soft/hard tissue crown lengthening is required before crown placement (50).

Type II, Div 1, A: This includes fracture of the posterior teeth involving one cusp only, due to either masticatory stress or trauma. These cases can be restored with cast inlay/onlay, direct or indirect composite, CAD-CAM generated porcelain restorations. In maxillary premolar 
fracture of one cusp, the pulp may be involved, and the preferred treatment is root canal therapy before the tooth is permanently restored by use of a post and core and cast crown (50).

Type II, Div 1, B: This includes fracture of the posterior teeth involving two cusps. Treatment involves cast inlay/onlay, direct or indirect composite, CAD-CAMgenerated inlays or onlays, pin-retained amalgams, and bonded amalgam. However, in maxillary premolars where there are only two cusps, and in mandibular premolars where the lingual cusp is rudimentary, restoration can be achieved with cast metal, CAD/CAM-generated onlays, or cast/ceramic crowns after root canal work, if required, and/or post and core according to need.

Type II, Div 1, C: This includes fractures of the posterior teeth involving three cusps. Treatment can be achieved with cast onlays, CAD/CAM generated onlays, or pin-retained amalgams/bonded amalgam, followed by cast crowns or ceramic crowns.

Type II, Div 1, D: This includes fractures of four or more cusps. These need to be restored with full cast/ceramic crowns. It is obvious that pulp vitality is of utmost importance, and a judicious decision regarding root canal therapy should be made in all cases before the final restoration.

In Type II, Div 2: Where fracture of a crown en masse occurs, the prognosis is generally poor and such teeth are usually extracted.

Type II, Div 3: Fractures of one or more roots of the posterior teeth. In single-rooted premolars or premolars with a longer trunk, the treatment is the same as that for anterior tooth fracture; however, for premolars with a short root trunk and molars with 2 or more roots, the treatment modality will differ depending on the location of the fracture and the number of roots involved. Resection of one root or, if required, hemisection, is the treatment of choice (106).

\section{Fracture of teeth in the vertical or longitudinal plane}

The clinical presentation of a vertical fracture may vary according to the position of the fracture, the tooth type, time elapsed after fracture, the periodontal condition of the tooth, and the bone architecture adjacent to the fracture. Such fractures can present as incomplete tooth fractures or with complete separation of the fragments in either a buccolingual or mesiodistal direction, that may or may not extend to the roots. Signs and symptoms may vary from mild discomfort on biting, chewing, or consumption of cold foods or drinks and pain on percussion in the early stages to gingival swelling and moderate to severe pain with or without sinus tract in the advanced stages $(26,37,116)$. Detailed anamnesis and various aids can be of help in diagnosing such cases $(23,26,37,117)$, and this is important for classification and treatment planning. Vertical or longitudinal tooth fractures restricted to the crown can be restored with bonded restorations with a guarded prognosis (26), but generally the prognosis is poor when the fracture line extends to the root $(26,37,117)$, especially in singlerooted teeth for which extraction is the only treatment (118). However, depending on direction or severity, root resection and hemisection may be applicable for multirooted teeth $(27,119)$. Neodymium:yttrium:aluminumgarnet or carbon dioxide laser beam treatment can be used to seal vertical root fracture lines (120). Tooth fragments can be immobilized by cementation with a customised stainless steel band, and a cast crown can be placed if the tooth remains vital and asymptomatic (106). Oliet (121) used cyanoacrylate, whereas Trope (122) used glass ionomer bone cement in conjunction with ePTFE GTR membrane for bonding after extraction of tooth fragments, and performed extraoral root canal therapy before replantation. Kawai and Masaka (123) treated vertical root fractures by bonding the fragments with Superbond (adhesive resin cement) and employing rotational replantation.

Type III, Div 1: This includes cases of cracked tooth syndrome. Hiatt (28) treated a case of incomplete fracture of a tooth that was otherwise sound using a crown, which acted as a splint, without any pulpal or periodontal therapy, whereas in another case where the fracture line could be identified in the dentine, root canal therapy and a cast crown were necessary. Davis and Overton (124) found that both bonded and non-bonded (pin-retained) complex amalgam restorations were effective for eliminating chewing pain in molars with incomplete fractures. Mittal et al. (125) reported a case where an orthodontic steel band was used to stabilize a cracked tooth, which was later reinforced with a composite restoration and finally with a full cast crown.

Type III, Div 2, A: These include fractures of anterior or posterior teeth where the fracture line passes buccolingually in the crown. The pulp may or may not be exposed in these cases. If the pulp is not exposed and the fracture fragments are not completely separated, the fragments may be bonded using adhesive resins or flowable composites; if the fragments are widely separated, the tooth may be stabilized using an orthodontic band and then restored with composites. If there is pulp exposure, root canal treatment is done after banding, and then the tooth is restored permanently using crowns. However, if the fragment is completely separated and cannot be reattached, 
it is removed and the rest of the tooth can be saved by post and core restorations or bicuspidisation, if this is practicable.

Type III, Div 2, B: Fractures of anterior or posterior teeth in a mesiodistal direction through the crown. In posterior teeth, the separated fragments are stabilized by orthodontic bands, root canal treatment is carried out, and the tooth restored with a composite restoration followed by placement of a full ceramic crown. In anterior teeth, in most cases, if the mobile fragment cannot be reattached, it is removed, the root canal is treated, and the tooth is restored with a post and core restoration, followed by a full crown.

Velmurugan et al. (126) used the canal projection technique for diagnosis of mesiodistal fracture where the fracture line extended to the pulpal floor. Takatsu et al. (127) advocated the wire-binding repositioning technique followed by root canal therapy and a cast crown for treatment of vertically fractured maxillary molars with widely separated segments.

In Type III, Div 3, A: Fractures in the buccolingual plane involving both the crown and root, with or without complete separation of the fragments. In mandibular molars, root bicuspidization or hemisection is the treatment of choice, and in maxillary molars, root resection can be done depending on the root that is fractured. The rest of the crown can be restored with a full crown $(64,106)$. In anterior teeth, however, the prognosis of such cases is generally poor. Vertucci (38) treated an incomplete buccolingual vertical fracture in the maxillary left second premolar root by surgical removal of the fractured buccal root surface and restored the remaining tooth with a retrograde zinc free amalgam restoration.

Type III, Div 3, B: Fractures involving the mesiodistal plane of both the crown and root in anterior or posterior teeth. If the fracture fragments are separated completely, they are removed, and the rest of the tooth is built up with metal-reinforced glass ionomer cement or composite and restored with a crown. David et al. (128) treated mesiodistal fractures through furcation using a rubber dam clamp to stabilise the fracture fragments, which were later reinforced with either composite, amalgam, or glass ionomer cement, and finally restored with a full cast crown.

In Type IV: Oblique fracture of the crown, root or both. After oblique fracture, the fragments may sometimes be held only by periodontal ligament fibers, and hence removal of the coronal fragment with orthodontic extrusion of the apical fragment may be required for restoration purposes (129). Immobilization of the fragments after oblique fracture can be maintained better than after transverse root fractures (99).

Thus with the recent advances in conservative techniques, preservation of natural teeth, even if they are horizontally or vertically fractured, is clinically possible, thereby reducing any psychological trauma and achieving an outcome closer to the natural situation. Although we believe that, in principle, conservation should be attempted as far as possible by applying modern principles of practical physics and engineering along with clinical considerations, it is sometimes not possible to select a conservative treatment option for some cases of root fracture and vertical tooth fracture. In such cases, extraction followed by an implant procedure and/or prosthetic replacement may be considered.

\section{References}

1. Glendor U, Marcenes W, Andreasen JO (2007) Classification, epidemiology and etiology. In: Textbook and color atlas of traumatic injuries to the teeth, 4th ed, Andreasen JO, Andreasen FM, Andersson L eds, Blackwell, Oxford, 217-254.

2. Dewhurst SN, Mason C, Roberts GJ (1998) Emergency treatment of orodental injuries: a review. Br J Oral Maxillofac Surg 36, 165-175.

3. Nair KB, Paul G (1986) Incidence and aetiology of fractures of the facio-maxillary skeleton in Trivandrum: a retrospective study. Br J Oral Maxillofac Surg 24, 40-43.

4. Hayter JP, Ward AJ, Smith EJ (1991) Maxillofacial trauma in severely injured patients. Br J Oral Maxillofac Surg 29, 370-373.

5. García-Godoy F (1968) A classification for traumatic injuries to primary and permanent teeth. J Pedod 5, 295-297.

6. Bakland LK (2002) Endodontic considerations in dental trauma. In: Endodontics, 5th ed, Ingle JI, Bakland LK eds, BC Decker, Hamilton, 795-843.

7. Simnosen RJ (1982) Restoration of a fractured central incisor using original tooth fragment. J Am Dent Assoc 105, 646-648.

8. Galea H (1984) An investigation of dental injuries treated in an acute care general hospital. J Am Dent Assoc 109, 434-438

9. Oztan MD, Sonat B (2001) Repair of untreated horizontal root fractures: two case reports. Dent Tramatol 17, 240-243.

10. Ellis RG, Davey KW (1970) The classification and treatment of injuries to the teeth of children. 5th ed, Year Book Publisher, Chicago, 1-231.

11. Marcenes W, Zabot NE, Traebert J (2001) Socioeconomic correlates of traumatic injuries to the permanent incisors in schoolchildren aged years in Blumenau, Brazil. Dent Traumatol 17, 222-226.

12. Terry DA (2003) Adhesive reattachment of a tooth 
fragment: the biological restoration. Pract Proced Aesthetic Dent 15, 403-409.

13. Andreasen JO, Ravn JJ (1972) Epidemiology of traumatic dental injuries to primary and permanent teeth in a Danish population sample. Int J Oral Surg 1, 235-239.

14. Andreasen JO (1970) Etiology and pathogeneseis of traumatic dental injuries. A clinical study of 1,298 cases. Scand J Dent Res 78, 329-342.

15. Welbury R, Kinirons MJ, Day P, Humphreys K, Gregg TA (2002) Outcomes for root fractured permanent incisors: a retrospective study. Pediatr Dent 24, 98-102.

16. Lee JU, Kwon KJ, Koh KJ (2004) Diagnostic accuracy of artificially induced vertical root fractures: a comparison of direct digital periapical images with conventional periapical images. Korean J Oral Maxillofac Radiol 34, 185-190.

17. Meister F Jr, Lommel TJ, Gerstein H (1980) Diagnosis and possible causes of vertical root fractures. Oral Surg Oral Med Oral Pathol 49, 243253.

18. Testori T, Badino M, Castagnola M (1993) Vertical root fractures in endodontically treated teeth: a clinical survey of 36 cases. J Endod 19, 87-91.

19. Youssefzadeh S, Gahleitner A, Dorffner R, Bernhart T, Kainberger FM (1999) Dental vertical root fractures: value of CT in detection. Radiology 210, 545-549.

20. Fuss Z, Lustig J, Tamse A (1999) Prevalence of vertical root fractures in extracted endodontically treated teeth. Int Endod J 32, 283-286

21. Vire DE (1991) Failure of endodontically treated teeth: classification and evaluation. J Endod 17, 338-342.

22. Gher ME Jr, Dunlap RM, Anderson MH, Kuhl LV (1987) Clinical survey of fractured teeth. J Am Dent Assoc 114, 174-177.

23. Moule AJ, Kahler B (1999) Diagnosis and management of teeth with vertical root fractures. Aust Dent J 44, 75-87.

24. Blender IB, Freedland JB (1983) Adult root fracture. J Am Dent Assoc 107, 413-419.

25. Tamse A, Fuss Z, Lustig J, Kaplavi J (1999) An evaluation of endodontically treated vertically fractured teeth. J Endod 25, 506-508.

26. Cohen S, Blanco L, Berman L (2003) Vertical root fractures: clinical and radiographic diagnosis. J Am Dent Assoc 134, 434-441.

27. Peciuliene V, Rimkuviene J (2004) Vertical root fractures in endodontically teated teeth: a clinical survey. Stomatologija 6, 77-80.

28. Hiatt WH (1973) Incomplete crown-root fracture in pulpal-periodontal disease. J Periodontol 44, 369379.

29. Plant JJ, Uchin RA (1976) Endodontic failures due to vertical root fractures: two case reports. J Endod 2, 53-55.

30. Holcomb JQ, Pitts DL, Nicholls JI (1987) Further investigation of spreader loads required to cause vertical root fracture during lateral investigation. $\mathrm{J}$ Endod 13, 277-284.

31. Silvestri AR (1976) The undiagnosed split-root syndrome. J Am Dent Assoc 92, 930-935.

32. Bastone EB, Freer TJ, McNamara JR (2000) Epidemiology of dental trauma: a review of the literature. Aust Dent J 45, 2-9.

33. Polson AM (1977) Periodontal destruction associated with vertical root fracture. J Periodontol 48, 27-32.

34. Lommel TJ, Meister F, Gerstein H, Davies EE, Tilk MA (1978) Alveolar bone loss associated with vertical root fractures. Report of six cases. Oral Surg Oral Med Oral Pathol 45, 909-919.

35. Wechsler SM, Vogel RI, Fishelberg G, Shovlin FE (1978) Iatrogenic root fractures: a case report. J Endod 4, 251-253.

36. Meister F Jr, Lommel TJ, Gerstein H, Bell WA (1981) An additional clinical observation in two cases of vertical root fracture. Oral Surg Oral Med Oral Pathol 52, 91-96.

37. Lin LM, Langeland K (1982) Vertical root fracture. J Endod 8, 558-562.

38. Vertucci FJ (1985) Management of a vertical root fracture. J Endod 11, 126-131.

39. Johnson R (1981) Descriptive classification of traumatic injuries to the teeth and supporting structures. J Am Dent Assoc 102, 195-197.

40. Ellis RG (1961) The classification and treatment of injuries to the teeth of children. 4th ed, Year Book Publisher, Chicago, 1-229.

41. Andreasen JO (1981) Traumatic injuries of the teeth. 2nd ed, Munksgaard, Copenhagen, 19-24.

42. Spinas E, Altana M (2002) A new classification for crown fractures of teeth. J Clin Pediatr Dent 26, 225-231.

43. Brauer JC (1936) Treatment and restoration of fractured permanent anterior teeth. J Am Dent Assoc 23, 2323-2336.

44. Adams FR (1944) Traumatized and fractured young teeth. J Am Dent Assoc 31, 241-248.

45. Hogeboom FE (1946) Practical pedodontia or juvenile operative dentistry and public health 
dentistry. 5th ed, CV Mosby, St Louis, 288-314.

46. Sweet CA (1955) A classification and treatment for traumatised anterior teeth. J Dent Child 22, 144149.

47. Rabinowitch BZ (1956) The fractured incisor. Pediatr Clin North Am 3, 979-994.

48. Bennett DT (1963) Traumatised anterior teeth. I. Assessing the injury and principles of treatment. $\mathrm{Br}$ Dent J 115, 309-311.

49. Hargreaves JA, Craig JW (1970) The management of traumatised anterior teeth of children. Livingstone, Edinburgh.

50. Silvestri AR Jr, Singh I (1978) Treatment rationale of fractured posterior teeth. J Am Dent Assoc 97, 806-816.

51. World Health Organization (1978) Application of the international classification of diseases to dentistry and stomatology, ICD-DA. 2nd ed, WHO, Geneve.

52. Heithersay GS, Moule AJ (1982) Anterior subgingival fractures: a review of treatment alternatives. Aust Dent J 27, 368-376.

53. Pulver F (1982) Treatment of trauma to the young permanent dentition. Dent Clin North Am 26, 525554.

54. MacDonald RE, Avery DR (1978) Dentistry for the child and adolescent. 3rd ed, Mosby, St Louis, 301342.

55. McDonald RE, Avery DR (1983) Dentistry for the child and adolescent. 4th ed, Mosby, St Louis, 433447.

56. Luebke RG (1984) Vertical crown-root fractures in posterior teeth. Dent Clin North Am 28, 883-894.

57. Ellis SGS (2001) Incomplete tooth fracture proposal for a new definition. Br Dent J 190, 424428.

58. Basrani E (1985) Fractures of teeth: prevention and treatment of the vital and non-vital pulp. Lea \& Febiger, Philadelphia, 4.

59. Dean JA, Avery DR, Swartz ML (1986) Attachment of anterior tooth fragments. Pediatr Dent 8, 139-143.

60. World Health Organization (1992) Application of international classification of diseases to dentistry and stomatology, ICD-DA. 3rd ed, WHO, Geneve.

61. Feiglin B (1995) Clinical management of transverse root fractures. Dent Clin North Am 39, 53-78.

62. International Association of Dental Traumatology (2001) Guidelines for the evaluation and management of traumatic dental injuries. Dent Traumatol 17, 1-4, 49-52, 97-102, 145-148.

63. Berman LH, Blanco L, Cohen S (2007) A clinical guide to dental traumatology. Mosby Elsevier, St
Louis, 4-5.

64. Wagnild G, Muller K (2006) Restoration of endodontically treated teeth. In: Pathways of the pulp, 9th ed, Cohen S, Hargreaves KM eds, Mosby, St Louis, 786-821.

65. Chosack A, Eidelman EM (1964) Rehabilitation of a fractured incisor using the patient's natural crown - case report. J Dent Child 31, 19-21.

66. Ozel E, Cildir A, Ozel Y (2008) Reattachment of anterior tooth fragment using self-etching adhesive: a case report. J Contemp Dent Pract 9, 77-83.

67. Simnosen RJ (1979) Traumatic fracture restoration: an alternative use of the acid etch-technique. Quintessence Int Dent Dig 10, 15-22.

68. Diangelis AJ, Jungbluth M (1992) Reattaching fractured tooth segments: an esthetic alternative. J Am Dent Assoc 123, 58-63.

69. Burke FJ (1991) Reattachment of a fractured central incisor tooth fragment. Br Dent J 170, 223-225.

70. Walker M (1996) Fractured-tooth fragment reattachment. Gen Dent 44, 434-436.

71. Davis MJ, Roth J, Levi M (1993) Marginal integrity of adhesive fracture restorations: chamfer versus bevel. Quintessence Int Dent Dig 14, 1135-1146.

72. Andreasen FM, Norén JG, Andreasen JO, Engelhardtsen S, Lindh-Strömberg U (1995) Long term survival of fragment bonding in the treatment of fractured crowns: a multicenter clinical study. Quintessence Int 26, 669-681.

73. Hedge RJ (2003) Tooth fragment reattachment - an esthetic alternative: report of a case. J Indian Soc Pedod Prev Dent 21, 117-119.

74. Baratieri LN, Monteiro Junior S, de Albuquerque FM, Vieira LC, de Andrada MA, de Melo Filho JC (1994) Reattachment of a tooth fragment with a "new" adhesive system: a case report. Quintessence Int 25, 91-96.

75. Reis A, Francci C, Loguercio AD, Carrilho MR, Rodriques Filho LE (2001) Re-attachment of anterior fractured teeth: fracture strength using different techniques. Oper Dent 26, 287-294.

76. Reis A, Kraul A, Francci C, de Assis TGR, Crivelli DD, Oda M, Loguercio AD (2002) Reattachment of anterior fractured teeth: fracture strength using different materials. Oper Dent 27, 621-627.

77. Andreasen FM, Steinhardt U, Bille M, Munksgaard EC (1993) Bonding of enamel-dentine crown fragments after crown fracture. An experimental study using bonding agents. Endod Dent Traumatol 9, 111-114.

78. Badami AA, Dunne SM, Scheer B (1995) An in vitro 
investigation into the shear bond strengths of two dentine-bonding agents used in the reattachment of incisal edge fragments. Endod Dent Traumatol $11,129-135$.

79. Kanca J 3rd (1996) Replacement of a fractured incisor fragment over pulpal exposure: a long term case report. Quintessence Int 27, 829-832.

80. Pagliarini A, Rubini R, Rea M, Campese M (2000) Crown fractures: effectiveness of current enameldentine adhesives in reattachment of fractured fragments. Quintessence Int 31, 133-136.

81. Small BW (1996) Emergency reattachment of fractured tooth. Using dentine bonding agent and flowable composite. Oral Health 86, 33.

82. Farik B, Munksgaard EC, Andreasen JO, Kreiborg S (1999) Drying and rewetting anterior crown fragments prior to bonding. Endod Dent Traumatol 15, 113-116.

83. Farik B, Munksgaard EC (1999) Fracture strength of intact and fragment-bonded teeth at various velocities of the applied force. Eur J Oral Sc 107, 70-73.

84. Farik B, Munsgaard EC, Andreasen JO, Kreiborg S (2002) Fractured teeth bonded with dentin adhesives with and without unfilled resin. Dent Traumatol 18, 66-69.

85. Bruschi-Alonso RC, Alonso RC, Correr GM, Alves MC, Lewgoy HR, Sinhoreti MA, Puppin-Rontani RM, Correr-Sobrinho L (2010) Reattachment of anterior fractured teeth: effect of materials and techniques on impact strength. Dent Traumatol 26, 315-322.

86. Busato AL, Loguercio AD, Barbosa AN, Sanseverino Mdo C, Macedo RP, Baldissera RA (1998) Biological restorations using tooth fragments. Am J Dent 11, 46-49.

87. Trushkowsky RD (1998) Esthetic, biologic and restorative considerations in coronal segment reattachment for a fractured tooth: a clinical report. J Prosthet Dent 79, 115-119.

88. McDonald RE, Avery DR, Lynch TR (2007) Management of trauma to the teeth and supporting tissues. In: Dentistry for the child and adolescent, 8th ed, McDonald RE, Avery DR, Dean JA eds, Mosby, St Louis, 453-503.

89. Christensen GJ (1998) Posts and cores: state of the art. J Am Dent Assoc 129, 96-97.

90. McLean A (1998) Criteria for the predictably restorable endodontically treated tooth. J Can Dent Assoc 64, 652-656.

91. Melnick PR (2006) Preparation of the periodontium for restorative dentistry. In: Carranza's clinical periodontology, 10th ed, Newman MG, Takei HH, Klokkevold PR, Carranza FA eds, Saunders, St Louis, 1039-1049.

92. Andreasen FM, Andreasen JO, Bayer T (1989) Prognosis of root-fractured permanent incisors: prediction of healing modalities. Endod Dent Traumatol 5, 11-12.

93. Caliskan MK, Pehlivan V (1996) Prognosis of rootfractured permanent incisors. Endod Dent Traumatol $12,129-136$.

94. Terata R, Minami K, Kubota M (2005) Conservative treatment for root fracture located very close to gingiva. Dent Traumatol 21, 111-114.

95. Hovland EJ (1992) Horizontal root fractures. Treatment and repair. Dent Clin North Am 36, 509525.

96. Andreasen JO, Hjorting-Hansen E (1967) Intraalveolar root fractures: radiographic and histologic study of 50 cases. J Oral Surg 25, 414426.

97. al-Nazhan S, Andreasen JO, al-Bawardi S, al-Rouq $S$ (1995) Evaluation of the effect of delayed management of traumatized permanent teeth. J Endod 21, 391-393.

98. Andreasen JO, Andreasen FM, Mejare I, Cvek M (2004) Healing of 400 intra-alveolar root fractures. 1. Effect of pre-injury and injury factors such as sex, age, stage of root development, fracture type, location of fracture and severity of dislocation. Dent Traumatol 20, 192-202.

99. Feely L, Mackie IC, Macfarlane T (2003) An investigation of root-fractured permanent incisor teeth in children. Dent Traumatol 19, 52-54.

100. Cvek M, Andreasen JO, Borum MK (2001) Healing of 208 intra-alveolar root fractures in patients aged 7-17 years. Dent Traumatol 17, 53-62.

101. Cvek M, Majare I, Andreasen JO (2002) Healing and prognosis of teeth with intra-alveolar fractures involving the cervical part of the root. Dent Traumatol 18, 57-65.

102. Andreasen JO, Andreasen FM, Mejáre I, Cvek M (2004) Healing of 400 intra-alveolar root fractures. 2. Effect of treatment factors such as treatment delay, repositioning, splinting type and period and antibiotics. Dent Traumatol 20, 203-211.

103. Rabie G, Barnett F, Tronstad L (1988) Long-term splinting of maxillary incisor with intra-alveolar root fracture. Endod Dent Traumatol 4, 99-103.

104. Crona-Larsson G, Bjarnason S, Norén JG (1991) Effect of luxation injuries on permanent teeth. Endod 
Dent Traumatol 7, 199-206.

105. Qin M, Ge LH, Bai RH (2002) Use of a removable splint in the treatment of subluxated, luxated and root fractured anterior permanent teeth in children. Dent Traumatol 18, 81-85.

106. Zachrisson BU, Jacobsen I (1975) Long-term prognosis of 66 permanent anterior teeth with root fracture. Scand J Dent Res 83, 345-354.

107. Trope M, Blanco L, Chivan N, Sigurdsson A (2006) The role of endodontics after dental traumatic injuries. In: Pathways of the pulp, 9th ed, Cohen S, Hargreaves KM eds, Mosby, St Louis, 610-649.

108. Cvek M, Mejàre I, Andreasen JO (2004) Conservative endodontic treatment of teeth fractured in the middle or apical part of the root. Dent Traumatol 20, 261-269.

109. Rafter M (2005) Apexification: a review. Dent Traumatol 21, 1-8.

110. Maroto M, Barberia E, Planells P, Vera V (2003) Treatment of a non-vital immature incisor with mineral trioxide aggregate (MTA). Dent Traumatol 19, 165-169.

111. Gomes AP, de Araujo EA, Gonçalves SEP, Kräft R (2001) Treatment of traumatized permanent incisors with crown and root fractures: a case report. Dent Traumatol 17, 236-239.

112. Talim ST, Gohil KS (1974) Management of coronal fractures of permanent posterior teeth. J Prosthet Dent 31, 172-178.

113. Gibbs LW (1954) Cuspal fracture odontalgia. Dent Dig 50, 158-160.

114. Snyder DE (1976) The cracked-tooth syndrome and fractured posterior cusp. Oral Surg Oral Med Oral Pathol 41, 698-704.

115. Gilmore HW, Lund MR, Bales CDJ, Vernetti JP (1982) Operative Dentistry. 4th ed, Mosby, St Louis, 260.

116. Sturdevant JR (2006) Class II cast metal restoration. In: Sturdevant's art and science of operative dentistry, 5th ed, Roberson TM, Heymann HO, Swift EJ eds, Mosby, St Louis, 847-915.

117. Linaburg RG, Marshall FJ (1973) The diagnosis and treatment of vertical root fractures: report of case.
J Am Dent Assoc 86, 679-683.

118. Dua KK, Kundabala M, Bhat KS (2004) Endodntic miscellany: 1. An unusual vertical root fracture. Endodontology 16, 23-26.

119. Pitts DL, Natkin E (1983) Diagnosis and treatment of vertical root fractures. J Endod 9, 338-346.

120. Arakawa S, Cobb CM, Rapley JW, Killoy WJ, Spencer P (1996) Treatment of root fracture by $\mathrm{CO} 2$ and Nd:YAG lasers: an in vitro study. J Endod 22, 662-667

121. Oliet S (1984) Treating vertical root fractures. J Endod 10, 391-396.

122. Trope M, Rosenberg ES (1992) Multidisciplinary approach to the repair of vertically fractured teeth. J Endod 18, 460-463.

123. Kawai K, Masaka N (2002) Vertical root fracture treated by bonding fragments and rotational replantation. Dent Traumatol 18, 42-45.

124. Davis R, Overton JO (2000) Efficacy of bonded and nonbonded amalgam in the treatment of teeth with incomplete fractures. J Am Dent Assoc 131, 469-478.

125. Mittal N, Sharma V, Minocha A (2006) Management of cracked teeth - a case report. Endodontology, 3944.

126. Velmurugan N, Bhargavi N, Lakshmi N, Kandaswamy D (2007) Restoration of a vertical tooth fracture and a badly mutilated tooth using canal projection. Indian J Dent Res 18, 87-89.

127. Takatsu T, Sano H, Burrow MF (1995) Treatment and prognosis of a vertically fractured maxillary molar with widely separated segments: a case report. Quintessence Int 26, 479-484.

128. David AH, Sergio AM, Itikawa GH (2004) Restoration of fractured teeth - a long term study. available onine at. www.mynewsmile.com/fracturedtooth.htm

129. Heda CB, Heda AA, Kulkarni SS (2006) A multidiciplinary approach in the management of a traumatised tooth with complicated crown-root fracture: a case report. J Indian Soc Pedod Prev Dent 24, 197-200. 